\title{
The Potential of Stem Bark of Kayu Sarampa (Xylocarpus moluccensis (Lam.) M. Roen)) as a-glucosidase Inhibitor
}

\author{
Fitri Santy Budiarso ${ }^{1}$, Berna Elya $^{1, *}$, Muhammad Hanafi ${ }^{2}$, Roshamur Cahyan Forestrania ${ }^{1}$
}

\section{Fitri Santy Budiarso', Berna Elya ${ }^{1, *}$, Muhammad Hanafi², Roshamur Cahyan Forestrania ${ }^{1}$}

${ }^{1}$ Faculty of Pharmacy, Universitas Indonesia, Kampus UI Depok, INDONESIA.

IIndonesian Institute of Sciences and Faculty of Pharmacy, University of Pancasila, INDONESIA.

\section{Correspondence}

\section{Berna Elya}

Professor and Lecturer at the Faculty of Pharmacy, Universitas Indonesia, INDONESIA.

E-mail: berna.elya@farmasi.ui.ac.id History

- Submission Date: 20-05-2020;

- Review completed: 03-07-2020;

- Accepted Date: 15-07-2020.

DOI : 10.5530/pj.2020.12.189

Article Available online http://www.phcogj.com/v12/i6

\section{Copyright}

(C) 2020 Phcogj.Com. This is an openaccess article distributed under the terms of the Creative Commons Attribution 4.0 International license.

\begin{abstract}
Introduction: The prevalence of diabetes mellitus type 2 in the world is more than 230 million people, increases about 3\% in a year. Kayu Sarampa or Nyirih batu (Xylocarpus moluccensis (Lam.) M. Roen) has traditionally been used to treat diabetic patient by native people in Ratahan, North Celebes, Indonesia. Therefore, this research was sequentially extracted bioactive component from stem bark of kayu sarampa showed alpha glucosidase inhibitor. Objective: To assess antioxidants and alpha glucosidase inhibitory activity of hexane, ethyl acetate, and methanol extract from stem bark of Kayu Sarampa. Method: The Stem bark was extracted with Reflux method using hexane, ethyl acetate, and methanol as mobile phae/solvent. The Hexane Extract (HE), Ethyl Acetic Extract (EAE) and Methanol Extract (ME) were subjected to the antioxidant activity assay by the 2.2-diphenyl-1-picrylhydrazyl (DPPH) radical scavenging and the ferric-reducing antioxidant power (FRAP) method. Antidiabetic activity was determined by enzymatic alpha-glucosidase inhibitor. Results: The extract which had the highest activity based on the DPPH test and FRAP test was the ME compared with EAE, and HE with IC values of $16.51 \mu \mathrm{g} / \mathrm{mL}, 34.1051 \mu \mathrm{g} / \mathrm{mL}$, and $38.8251 \mu \mathrm{g} / \mathrm{mL}$, respectively. Ferrous equivalent antioxidant capacity (FeEAC) method, methanolic extract had a higher reduction capacity than the $\mathrm{EH}$ and EEA which were $148.96 \mu \mathrm{mol} / \mathrm{gr}, 48.96 \mu \mathrm{mol} / \mathrm{gr}$, and $148.96 \mu \mathrm{mol} / \mathrm{gr}$, respectively. The result showed that kayu sarampa stem bark exhibited antidiabetic activity due to its high inhibition compared with control (acarbose). ME showed inhibition of 53,11\% followed with EAE 49,7\%, HE 44,53\%, and acarbose as control 29,32\%.Conclusion: stem bark of kayu sarampa have bioactive component as alpha glucosidase inhibitor
\end{abstract}

Key words: Kayu Sarampa, Antidiabetic, Alpha-glucosidase inhibitor, Antioxidant.

\section{INTRODUCTION}

The prevalence of diabetes mellitus type 2 in the world is more than 230 million people, increases about $3 \%$ in a year. ${ }^{1}$ Hyperglycemia accelerates the formation of reactive oxygen species that increases lipid, DNA and protein modification in human tissue. ${ }^{2}$ Molecular modification in some tissues causes an imbalance between protective antioxidant and free radical production. That was the beginning of oxidative damage which is known as oxidative stress. ${ }^{3}$

Antioxidant was used to inhibit or minimalize oxidative damage. One common method which is used to evaluate antioxidant activity is 1,1-diphenyl2-pilcrylhidrazyl (DPPH). ${ }^{4}$ This method measures synthetic radicals DPPH in a polar solute such as ethanol or methanol at room temperature which is scavenged by an antioxidant compound. ${ }^{5}$

Native people in Ratahan, Sulawesi Utara use batu Nyirih (Xylocarpus moluccensis) to treat diabetic patients. This plant is known as Kayu sarampa. Xylocarpus genus spread from India beach, Ceylon, Burma, Malaysia and Indonesia. Many researchers study about active components in Kayu Sarampa. It contains antibacterial, antidiabetes, antioxidant, antifilarial, antidiarrhea, antidepressant and cytotoxic activity. ${ }^{6}$ Kayu sarampa can be used to treat fever, joint pain, headache, and disorders such as cholerae, constipation, and diarrhea ${ }^{7}$.

Methanol extract of $X$. moluccensis was found to be significantly effective in scavenging DPPH method. The fruits of $X$. moluccensis contain limonoid which can change enzyme activity to metabolize glucose and increase glucose absorption by muscle tissue. ${ }^{9}$ In humans, alpha-glucosidase enzymes aid the digestion of dietary carbohydrates and starches to produce glucose for intestinal absorption, which in turn, leads to an increase in blood glucose levels. Elbakyan (1998) reported that a compound obtained from an isolate of ethyl acetic fraction was 2-methoxy-5-(1propenyl) phenol and 2-methoxy-4-(1-propenyl) phenol with $\mathrm{m} / \mathrm{z} 180$ and 164 , respectively. ${ }^{10}$

Extraction is an initial step to separate bioactive from plants. Solvent extraction is the most common technique to extract natural products from plants. ${ }^{11}$ Secondary metabolites in plants have different polarity. Therefore, extraction with various solvent polarities was preferable. ${ }^{12}$ The use of solvent-based on its polarity can be applied to dry powder of plant tissue using reflux. It was done at discontinued high temperature condition although soxhlet was done under continued high temperature. The advantages of reflux compared with soxhlet was the less use of solvent, and compared to creation, it only needs a short time of extraction. ${ }^{13}$ Therefore, this research uses sequential reflux extraction in hexane, ethyl 
acetate, and methanol solvent. Kayu sarampa plant consists of bioactive components used to cure diabetic patients. However, there is no evidence of the use of stem bark of $X$. moluccensis to inhibit $\alpha$-glucosidase. This research was done to sequentially extract bioactive component from stem bark of $X$. moluccensis and asses their a-glucosidase inhibitory activity.

\section{MATERIAL}

\section{Plant material}

Sample used in this study was the stem bark of $X$. moluccensis which was obtained from Ratatotok district, North Sulawesi and was identified by Herbarium Bogoriensis, Biological research centre, Indonesian Institute of Science.

\section{Chemicals}

Chemicals used in this study were Phosphate buffer $\mathrm{pH} 7$, dichloromethane, dimethyl sulphoxide (Merck cat. 3.17275, Germany), Alpha-glucosidase (Wako Pure Chemical Industries Ltd., Japan), Acarbose, ethanol, ethyl acetate, methanol, $\mathrm{n}$-hexane, para nitrophenyl alpha-D-glucopyranoside (Wako Pure Chemical Industries Ltd. EC 3.2.1.20, Jepang), Sodium carbonate (Merck cat. 1.09940, Germany), 1.1-diphenyl-2-picrylhidrazyl (DPPH), ascorbic acid (Sigma-Aldrich, A5960), Ferrous sulfate heptahydrate (MERCK, Germany)

\section{Sample preparation}

The stem bark of $X$. moluccensis. from Ratatotok, North Sulawesi, was freshly picked, collected, sorted, and dried. The Stem bark were then crushed until they became smaller.

\section{Microscopic observations by scanning electron microscope (SEM) and light microscope}

Microscopic analysis of Leaf and Stembark of X. moluccensis was performed using SEM Model: JSM - IT 200 in the Zoology Field of the Biology Research Centre - Indonesian Institute of Sciences (LIPI), Cibinong, and the observations were also made using a light microscope.

\section{Extraction and Fractionation}

Four kilograms of stem bark powder of dried X. moluccensis was extracted using hexane. Extraction was initially done using reflux apparatus to obtain hexane extract. Hexane extract then was evaporated using a rotary evaporator to obtain a crude hexane extract (HE). It was stored under room temperature. The same way was done for ethyl acetate solvent to obtain ethyl acetate extract (EAE). Then, methanol was used to extract the residue to obtain methanolic extract (ME).

\section{Determination of free radical 1.1-diphenyl-2-} picrylhidrazyl (DPPH) scavenging activity

DPPH radical scavenging activity was done according to the procedure declared by Burda \& Oleszek (2001) with slight modification. ${ }^{14}$ Five hundred microliter extracts were added into $1.5 \mathrm{~mL}$ DPPH solution, mixed for 2 minutes, and incubated in dark room for 30 minutes. The absorbance of the solution was measured for 5 minutes before incubation time ends. Color change from purple to yellow means free radical scavenging efficiency. Free radical scavenging activity was calculated as the percentages of color decreasing of DPPH solution using the following equation:

Free radical scavenging activity $(\%)=\left(1-\frac{\text { sample absorbance }}{\text { control absorbance }}\right) \times 100 \%$

After the inhibition percentage of each concentration was obtained, linear regression was made so that the equation $y=a+b x$ was obtained, where $\mathrm{x}$ is the concentration $(\mu \mathrm{g} / \mathrm{mL})$ and $\mathrm{y}$ is the percentage of inhibition (\%). Antioxidant activity is expressed by $50 \%$ Inhibitory Concentration or $\mathrm{IC}_{50}$, which is the concentration of the sample that can reduce DPPH radicals by $50 \%$ from the initial concentration.

\section{FRAP assay test}

This tes was conducted using the method described by Bhagat et al Acetate buffer (300 mM, pH 3.6), TPTZ (2,4,6-tripyridyl-s-triazine) $10 \mathrm{mM}$ in $40 \mathrm{mM} \mathrm{HCl}, \mathrm{FeCl} 3 \bullet 6 \mathrm{H} 2 \mathrm{O}(20 \mathrm{mM})$. The working FRAP reagent was prepared by mixing the three solutions in the ratio of 10:1:1. Extract of stem bark of X. moluccensis $(100 \mu \mathrm{L})$ was mixed with $3 \mathrm{~mL}$ of working FRAP reagent and the absorbance was measured at $598 \mathrm{~nm}$ after vertexing. Methanol solutions of $\mathrm{FeSO} 4 \cdot 7 \mathrm{H} 2 \mathrm{O}$ ranging from 100 to $2000 \mu \mathrm{M}$ were prepared and used for the preparation of the calibration curve of known $\mathrm{Fe} 2+$ concentration. The parameter equivalent concentration was defined as the concentration of antioxidant have a Ferric-TPTZ reducing ability equivalent to that of $1 \mathrm{mM} \mathrm{FeSO} 4 \cdot 7 \mathrm{H} 2 \mathrm{O}$.

\section{Standard and sample examination of Alpha-glucosidase Inhibitor}

Acarbose as a standard and sample was weighed and dissolved in phosphate buffer solution $\mathrm{pH}$ 6.8. Sample with low solubility in phosphate buffer was dissolved in maximum 10\% DMSO. Then standard and sample were diluted into some concentrations.

Thirty microliter standard and sample solution were added to $17 \mu \mathrm{L}$ PNPG substrate. The solution was incubated for 5 minutes at $37^{\circ} \mathrm{C}$, and added to $17 \mu \mathrm{L}$ alpha-glucosidase solution. Solution was incubated again at $37^{\circ} \mathrm{C}$ for 15 minutes. After that, $100 \mu \mathrm{L}$ sodium carbonate 267 $\mathrm{mM}$ was added. Solution absorbance was measured using a microplate reader at $405 \mathrm{~nm}$ wavelength.

Alpha-glucosidase inhibitory activity was calculated by the following equation ${ }^{16}$ :

$\%$ Alpha - glucosidase Inhibition $=\frac{\text { blank control absorbance }- \text { sample absorbance }}{\text { blank control absorbance }} \times 100 \%$

\section{Statistical analysis}

All the experimental data do triplicates and the results are expressed as mean $\pm \mathrm{SD}$. $\mathrm{IC}_{50}$ was analyzed using Probit. Antioxidant power and alpha-glucosidase inhibitory activity were analyzed using One way ANOVA analysis followed by Duncan Multiple Range Test. Analysis was performed using SPSS software version 20.

\section{RESULTS AND DISCUSSIONS}

\section{Extraction}

X. moluccensis was extracted sequentially using reflux with hexane, ethyl acetate, and methanol as the solvent. Relux is an extraction using heat. Miller (1975) stated that heating under reflux process can increase the possibility to damage tissue membrane of plant material, so that solvent can penetrate into tissue void which contains active components. ${ }^{7}$ Active components will dissolve in because of its different concentration between active component inside and outside the tissue, so concentrated solution is pulled outside. The yield of reflux sequential extraction was displayed in the following table 1 .

Table 1 shows that methanolic extract exhibits the highest yield followed with EEA and EH. A polar bioactive component from kayu sarampa extract is dissolved in methanol. The yield of the extract is depending on the effectivity of solvent used for extraction. High yield of extract means high extracted component.

Microscopic observations by scanning electron 


\section{microscope (SEM) and light microscope}

\section{Antioxidant activity}

Antioxidant activity of kayu sarampa was evaluated using DPPH and FRAP methods.

\section{Free Radicals DPPH Scavenging Activity}

The evaluated $X$. moluccensis concentration were 25, 50, 75, 100, and 125 $\mathrm{mg} / \mathrm{L}$, respectively. Free radical DPPH commonly used as substrate to evaluate antioxidant activity. Antioxidant properties of $X$. moluccensis extract reacted with $\mathrm{DPPH}$, the solution color changed from purple to yellow. The change in solution color affected to DPPH absorbance. The higher concentration of antioxidant component in solution, the lower the absorbance of DPPH.

The change in solution color is caused by a component that donates hydrogen atom to DPPH radical. Antioxidant reducted DPPH radical to more stable form namely DPPH-H (2,2-diphenyl-1-picrylhidrazine). ${ }^{4}$ Evaluation of antioxidant activity using DPPH method is presented in Figure 4 .

Figure 4 showed that antioxidant activity of $X$. moluccensis through DPPH method is increased in a concentration-dependent manner. Methanol extract exhibited the highest free radical DPPH scavenging activity $82,93 \%$, followed with ethyl acetate extract $74,75 \%$, and Hexane extract $27,83 \%$, respectively. Ascorbic acid as antioxidant standard exhibited $88,09 \%$ activity. Lai et al. (2001) stated that antioxidant activity using radical DPPH mostly increase in a concentrationdependent manner. ${ }^{17}$

$\mathrm{IC}_{50}$ value represents the ability of $X$. moluccensis extract to scavenge $50 \%$ of DPPH free radical. The lowest $\mathrm{IC}_{50}$ value of an extract represents high antioxidant activity. ${ }^{18} \mathrm{IC}_{50}$ was obtained from a regression linear equation in Figure 1 which plotted $\mathrm{x}$ axis (concentration) with $\mathrm{y}$ axis (free radical DPPH scavenging activity), so a regression equation and $\mathrm{IC}_{50}$ obtained is presented in Table 3.

Table 3 showed that ME $\mathrm{IC}_{50}$ of $X$. moluccensis exhibits the highest activity compared with $\mathrm{EAE}$, and $\mathrm{HE}$. $\mathrm{IC}_{50}$ value of an extract represents its potential to inhibit free radicals. A strong level $\mathrm{IC}_{50}$ categorized with $\mathrm{IC}_{50}$ value $50-100 \mathrm{mg} / \mathrm{L}$, medium range category $100-250 \mathrm{mg} / \mathrm{L}$, and low level category was $250-500 \mathrm{mg} / \mathrm{L}^{19}$
High antioxidant activity of methanolic extract of kayu sarampa is caused by polar secondary metabolite such as flavonoid. Interaction of flavonoid with nitric oxide synthases (NOS) activity may modulate the NO production. Xanthine oxidase (XO) is considered as a key source of free radicals, and some flavonoids such as quercetin, silibin, and luteolin have been shown to inhibit such activity. Flavonoids may also reduce the activity of peroxidase and may inhibit the release of free radicals by neutrophils and activation of these cells by a 1 -antitrypsin. ${ }^{20}$

Ascorbic acid used as a control in this study is a strong antioxidant. $\mathrm{IC}_{50}$ of ascorbic acid exhibits $\mathrm{IC}_{50}$ value $10,49 \mathrm{mg} / \mathrm{L}$. It was caused possibly by 2 groups of hydroxy $(-\mathrm{OH})$ on its double bond which is easily oxidized by free radicals. In addition, vitamin $\mathrm{C}$ used in this study is a pure substance so it exhibits strong $\mathrm{IC}_{50}$ or high antioxidant activity. ${ }^{21}$

\section{Ferric reduction antioxidant power}

The FRAP method is a method of testing antioxidant activity through the ability of antioxidant compounds to reduce $\mathrm{Fe}^{3+}$ ions to $\mathrm{Fe}^{2+}$ in the presence of 2.4,6-tri (2-pyridyl)-s-triazine (TPTZ) in an acidic atmosphere which produces intensive blue colour from the $\mathrm{Fe}^{2+-} \mathrm{TPTZ}$ complex and causes an increase in absorbance when it is measured using a microplate reader at a maximum absorption of $593 \mathrm{~nm}$. In the test using the FRAP method, ferrous sulfate heptahydrate (FSH) is used as a standard. First, the standard FSH calibration curve is made. The antioxidant activity is measured based on the sample equality with the AFS standard. The linear regression equation of FSH obtained $y=$ $0.00257 x+0.04715$. Antioxidant power of sarampa extract is shown in following table 4 .

Table 4 shows that ME from $X$. moluccensis stembark exhibits higher antioxidant power compared to $\mathrm{HE}$ and EAE which are $148.96 \mu \mathrm{mol} /$ gr, $48.96 \mu \mathrm{mol} / \mathrm{gr}$, and $148.96 \mu \mathrm{mol} / \mathrm{gr}$, respectively. Statistical analysis reveals that antioxidant power of samples extracted with different solvent are significantly different $(\mathrm{p}<0.05)$. Based on the result presented in Table 4, samples extracted with methanol and ethyl acetic show higher antioxidant power compared to $n$-hexane extract. This is due to the high polarity of methanol and ethyl acetic, whilst hexane is non polar. These results are influenced by the polarity of solvent because methanol is the most polar solvent used in this experiment, while ethyl acetate and hexane in descending order were less polar than methanol. The higher total antioxidant content in extract means more compounds can reduce $\mathrm{Fe}^{3}+$ to $\mathrm{Fe}^{2}+$ (blue), and compounds that reduce $\mathrm{Fe}^{3}+$ is an

Table 1: The yield of $X$. moluccensis extraction.

\begin{tabular}{cccc}
\hline & HE & EAE & ME \\
\hline Extract weight $(\mathrm{g})$ & 24.3 & 63.38 & 625.56 \\
Yield \% & 1.215 & 3.169 & 31.278 \\
\hline
\end{tabular}

Note : hexane extract (HE), ethyl acetate extract (EAE), methanolic extract (ME)

Table 2: A summary of the $X$. moluccensis leaf side section.

\begin{tabular}{cccccc}
\hline Leaf Surface & $\begin{array}{c}\text { Distribution of } \\
\text { stomata on leaf } \\
\text { surface }\end{array}$ & $\begin{array}{c}\text { Morphological } \\
\text { type of mature } \\
\text { stomata }\end{array}$ & $\begin{array}{c}\text { Lenght } \\
(\mu \mathrm{m})\end{array}$ & $\begin{array}{c}\text { Sreadth } \\
(\mu \mathrm{m})\end{array}$ & Pore size $(\mu \mathrm{m})$ \\
\hline Upper & Hypostomatic & Paracytic & 0 & 0 & $30 \pm 0.5^{*}$ \\
Lower & Hypostomatic & Paracytic & $20 \pm 0.2$ & $10 \pm 05$ & $10 \pm 12$ \\
\hline
\end{tabular}

${ }^{*}$ SEM value

Table 3: Regression equation and $\mathrm{IC}_{50}$ of $X$. moluccens is extracted with different solvents.

\begin{tabular}{ccccc}
\hline & HE & EAE & ME & Ascorbic acid \\
\hline Regression Equation & $\mathrm{y}=0.2158 \mathrm{x}+0.9182$ & $\mathrm{y}=0.3007 \mathrm{x}+39.77$ & $\mathrm{y}=0.3197 \mathrm{x}+44.72$ & $\mathrm{y}=0.3788 \mathrm{x}+46.026$ \\
$\mathrm{IC}_{50}(\mu \mathrm{g} / \mathrm{L})$ & 38.82 & 34.10 & 16.51 & 10.49 \\
\hline
\end{tabular}

Note : hexane extract (HE), ethyl acetate extract (EAE), methanolic extract (ME) 
antioxidant compound. Prior et al 2005 states that methanol is a polar compound which is easy to position the hydrogen atoms of a compound or hydroxyl groups to form hydrogen bonds because the bonds would facilitate the transfer of protons (hydrogen atoms antioxidants). ${ }^{22}$

\section{Alpha-glucosidase inhibitory activity}

Concentration of stem bark kayu sarampa extract used in this test is 100 ppm. Alpha-glucosidase inhibitory activity of stem bark X. moluccensis extract was presented in Table 5.

The result shows that kayu sarampa stem bark exhibits antidiabetic activity due to its high inhibition compared with control. Methanolic extract shows inhibition $53,11 \%$ followed with ethyl acetate extract $49,7 \%$, Hexane extract $44,53 \%$, and acarbose as control $29,32 \%$.
Srivastava et al reported that antihyperglycemia and anti dyslipidemia activity of ethyl acetate fraction of X. moluccensis (EAXm) effectively increase glucose recovery, decrease blood glucose level and fructosamin serum dose in diabetic mice induced by streptozotocin. EAXm also decreases cholesterol serum, triglyceride, LDL cholesterol, but increases HDL cholesterol, liver function, and kidney fuction in HFD/ HSD-STZ mice for 10 consecutive days. Moreover, EAXm increases glucose absorption by muscle tissue L- 6 and inhibites alpha glucosidase enzyme in vitro with $\mathrm{IC}_{50} 28,4 \mu \mathrm{g} / \mathrm{ml}$. Although there is no research about secondary metabolite in the stem bark of $X$. moluccensis as a-glucosidase inhibitor. ${ }^{8}$

The secondary metabolite which possibly exhibites antidiabetic activity through $\alpha$-glucosidase inhibition in kayu sarampa is limonoid. Das et

Table 4: Antioxidant power using FRAP.

\begin{tabular}{ccc}
\hline Sample & $\begin{array}{c}\text { Antioxidant Power (FRAP) } \\
(\mu \text { mol Fell/g) }\end{array}$ & \% Scavenging (DPPH) \\
\hline Control (Ascorbic Acid) & $340.48 \pm 0.02$ & $85.67 \pm 0.03$ \\
n-Hexane & $48.96 \pm 1.01$ & $22.68 \pm 0.02$ \\
Ethyl Acetate & $131.84 \pm 0.03$ & $72.06 \pm 0.05$ \\
MeOH & $148.96 \pm 0.02$ & $75.94 \pm 0.65$ \\
\hline
\end{tabular}

Data is presented as the mean \pm standard deviation $(\mathrm{N}=3)$. Means with different letters are significantly different $(\mathrm{p}<0,05)$.

Table 5: Alpha-glucosidase inhibition activity at concentration 100 ppm.

\begin{tabular}{lllll}
\hline & HE & EAE & ME & Acarbose \\
\hline Percent Inhibition (\%) & 44.53 & 49.70 & 53.11 & 29.32 \\
\hline
\end{tabular}

Note : hexane extract (HE), ethyl acetate extract (EAE), methanolic extract (ME)

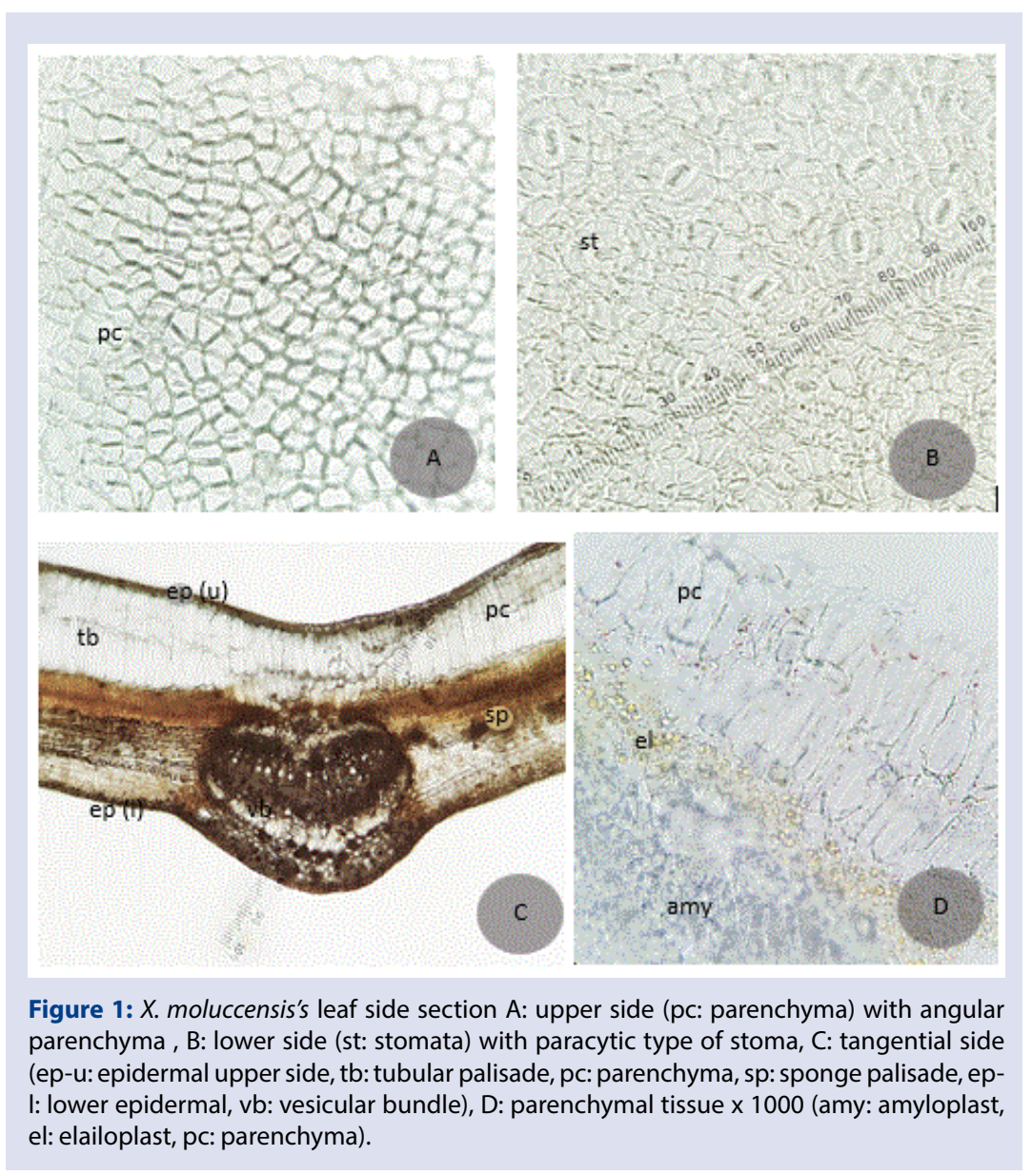



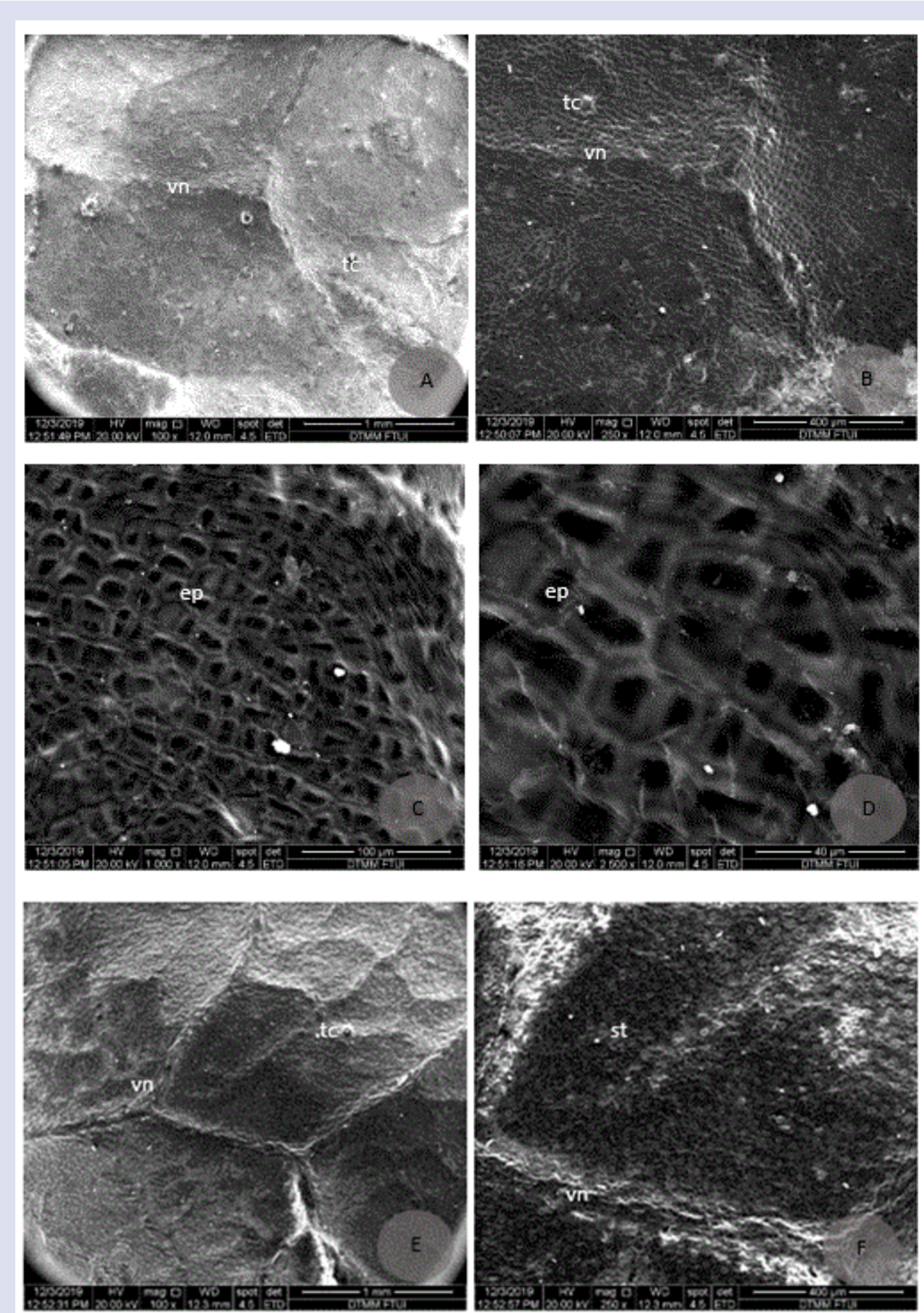

Figure 2: X. moluccensis's leaf side (SEM) A: upper side (vn: leaf's venular, tc: trichome) 100x, B: upper side 250x, C: upper side $100 \times$ (ep: epidermal tissue with angular parenchyma) , D: upper side 2.500x magnification, E: lower side 100x (vn: leaf's venular, tc: trichome), F: lower side 100x (vn: leaf's venular, st: stoma). 


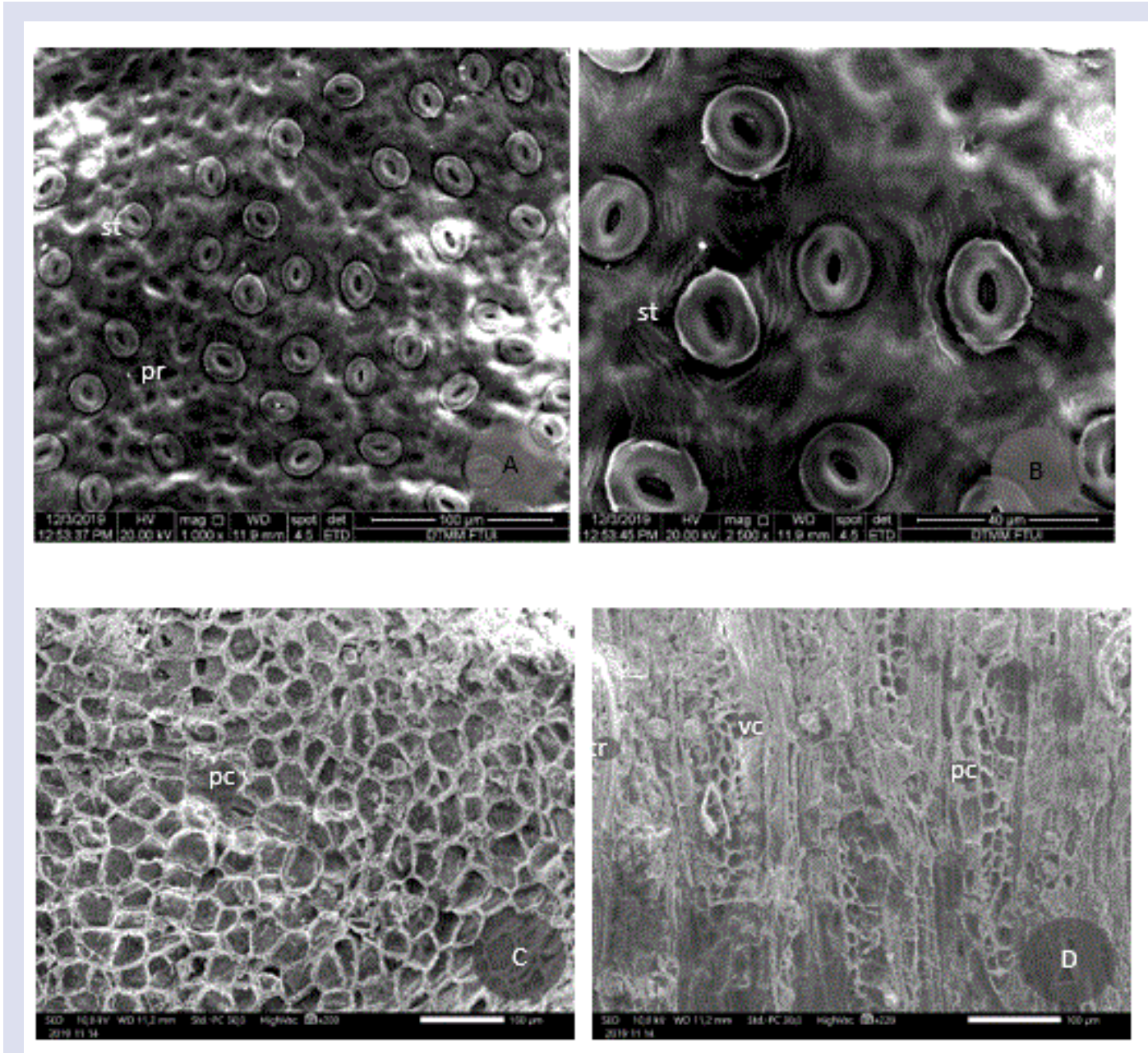

Figure 3: $X$. moluccensis's lower leaf side (A-B) and stem (C-D) (SEM) A: lower side leaf (pr: leaf's phore, st: stoma) 1000x magnification, B: lower side leaf $2.500 \times$ (st: stoma paracytic type with with distinct subsidiaries), C: tangential slice section of stem $100 \times$ magnification (pc: parenchyma cell of stem, irregular angular type), D: longitudinal side section of stem (vascular side, xylem) tr: tracheal tissue of xylem, vc: vascular, pc: xylem's parenchyma.

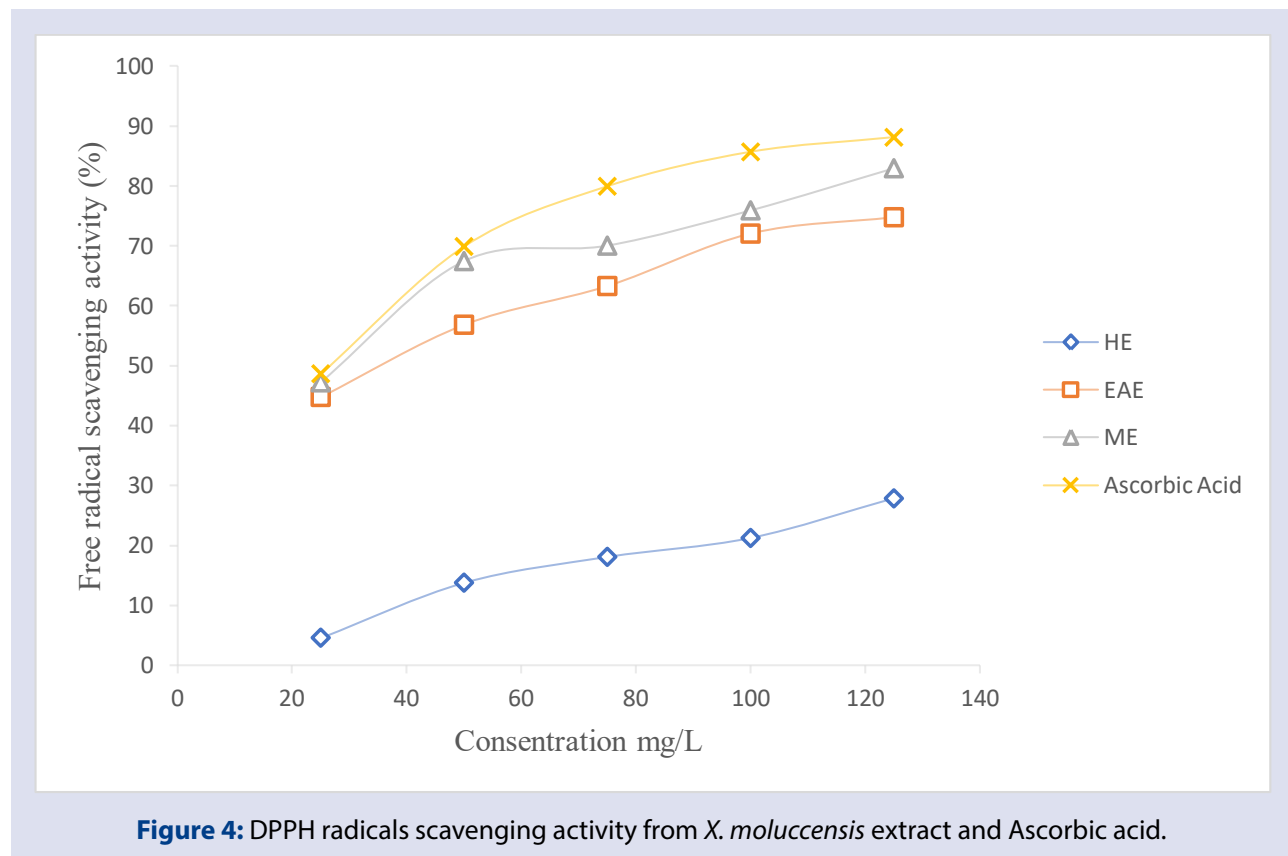


al reported that xyloccensin- $\mathrm{L}$ contains interaction and can bond when it is close to the target then confirm the possibility antidiabetic action mode by isolated compound from X. granatum. xyloccensin-L is a novel limonoid from X. granatum. ${ }^{23}$

\section{ACKNOWLEDGEMENT}

We would like to acknowledge the financial assistance obtained from the "PDUPT, Ministry of Research and Technology/National Research and Innovation Agency" grant (Nomor: NKB-90/UN2.RST/ HKP.05.00/2020).

\section{REFERENCES}

1. Ueno $Y$, Kizaki M, Nakagiri R, Kamiya T, Sumi H, Osawa T. Dietary glutathione protects rats from diabetic nephropathy and neuropathy. J Nutr. 2002;132:897900.

2. Nuttal SL, Dunne F, Kendal MJ, Martin U. Age-independent oxidative stress in elderly patiens with dependent non-insulin-dependent diabetes mellitus. Q J Med. 1999;92:33-8.

3. Prakash A. Antioxidant Activity. Medallion Laboratories: Analytical Progress. 2001;19:1-4.

4. Molyneux P. The Use of the Stable Free Radical Diphenylpicrylhydrazyl (DPPH) for Estimating Antioxidant Activity. J Sci Tech. 2004;26:211-557.

5. Droge W. Free radicals in the physiological control of cell function. Physiol Rev. 2002;82:47-95

6. Halliwel B, Gutteridge JMC. Free radical in biology and medicine. 3rd ed. New York: Oxford University Press. 2015; p.639-645.

7. Raja and Ravindranadh. A complete profile on Xylocarpus moluccensis traditional uses, pharmacological activities and phytoconstituents. World J Pharm Sci. 2014; 2(12):1770-7.

8. Srivastava AK, Tiwari P, Srivastava SP, Srivastava R, Mishra A, Rahuja N, et al. Antihyperglycaemic And Antidyslipidemic Activities In Ethyl Acetate Fraction Of Fruits Of Marine Mangrove Xylocarpus Moluccensis. International Journal of Pharmacy and Pharmaceutical Sciences. 2014;6(1):809-26.

9. Islam M, Sarifi-Rad J, Martoerell M, Ali J, et al. Chemical profile and therapeutic potentials of Xylocarpus moluccensis (Lam.) Roem.: A literature-based review. Journal of Ethnopharmacology. 2020;259.
10. Elbakyan A. Analytical Pyrolysis of Lignins. Analytical Pyrolysis of Natural Organic Polymers. 1998;9:327-51.327

11. Meydani SN, D Wu, MS Santos, dan MG Hayek. Antioxidants and Immune Response in Aged Persons: Overview of Present Evidence. American J of Clinical Nutrition. 1995;62:1462-76.

12. Rahbani-Nobar ME, Rahimi-Pour A, Rahbani-Nobar M, Adi-Beig F, Mirhashemi SM. Total antioxidant capacity, superoxide dismutase and glutathione peroxidase in diabetic patients. Medical Journal of Islamic Academy of Sciences. 1999;12(4):109-14.

13. Zhang OW, Lin L, Ye LW. Techniques For Extraction And Isolation Of Natural Products: A Comprehensive Review. Chin Med. 2018; 13:20

14. Burda A, Oleszek W. Antioxidant and Antiradical Activities of Flavonoids. J Agric Food Chem. 2001; 49:2774-9.

15. Bhagat M, Anand R, Datt R, Gupta V, Arya S. Green Synthesis of Silver Nanoparticles Using Aqueous Extract of Rosa brunonii Lindl and Their Morphological, Biological and Photocatalytic Characterizations. Journal of Inorganic and Organometallic Polymers and Materials. 2018.

16. Miller JM. Separation Methods in Chemical Analytics. John Wiley Publisher New York. 1975;105.

17. Lai, L-S., S-T. Chou, W-W. Chao. Studies on the antioxidative Actibities of Hsian-tsao (Mesona procumbens Hemsl) Leaf Gum. J Agric Food Chem. 2001;49:963-8.

18. Hussain T, Tan B, Yin Y, Blachier F. Oxidative Stress and Inflammation: What Polyphenols Can Do for Us. Hindawi Publishing Corporation: Oxidative Medicine and Cellular Longevity. 2016; 2.

19. Zhang Q, Satyanandamurty T, Shen Li, Wu J. Krishnolides A-D: New 2-Ketokhayanolides from the Krishna Mangrove, Xylocarpus moluccensis. Marine Drugs. 2017;15:333

20. Matuszewska A, Jaszek M, Stefaniuk D, Ciszewski T, Matuszewski L. PLoS One. 2018;13(6):8.

21. Padayatty S, Katz A, Wang Y, Eck P,Kwon O, Lee J, et al. Vitamin $C$ as an Antioxidant: Evaluation of Its Role in Disease Prevention. Journal of the American College of Nutrition. 2003; 22(1):18-35

22. Prior RL, Wu X, Schaich K. Standardized Methods for The Determination of Antioxidant Capacity and Phenolics in Foods and Dietary Supplements. Journal of Agricultural and Food Chemistry. 2005;53:4290-302.

23. Das SK, Samantaray D, Sahoo SK, Pradhan SK, Samanta L, Thatoi H. Bioactivity guided isolation of antidiabetic and antioxidant compound from Xylocarpus granatum J. Koenig bark. 3 Biotech. 2019;9(5). 


\section{GRAPHICAL ABSTRACT}
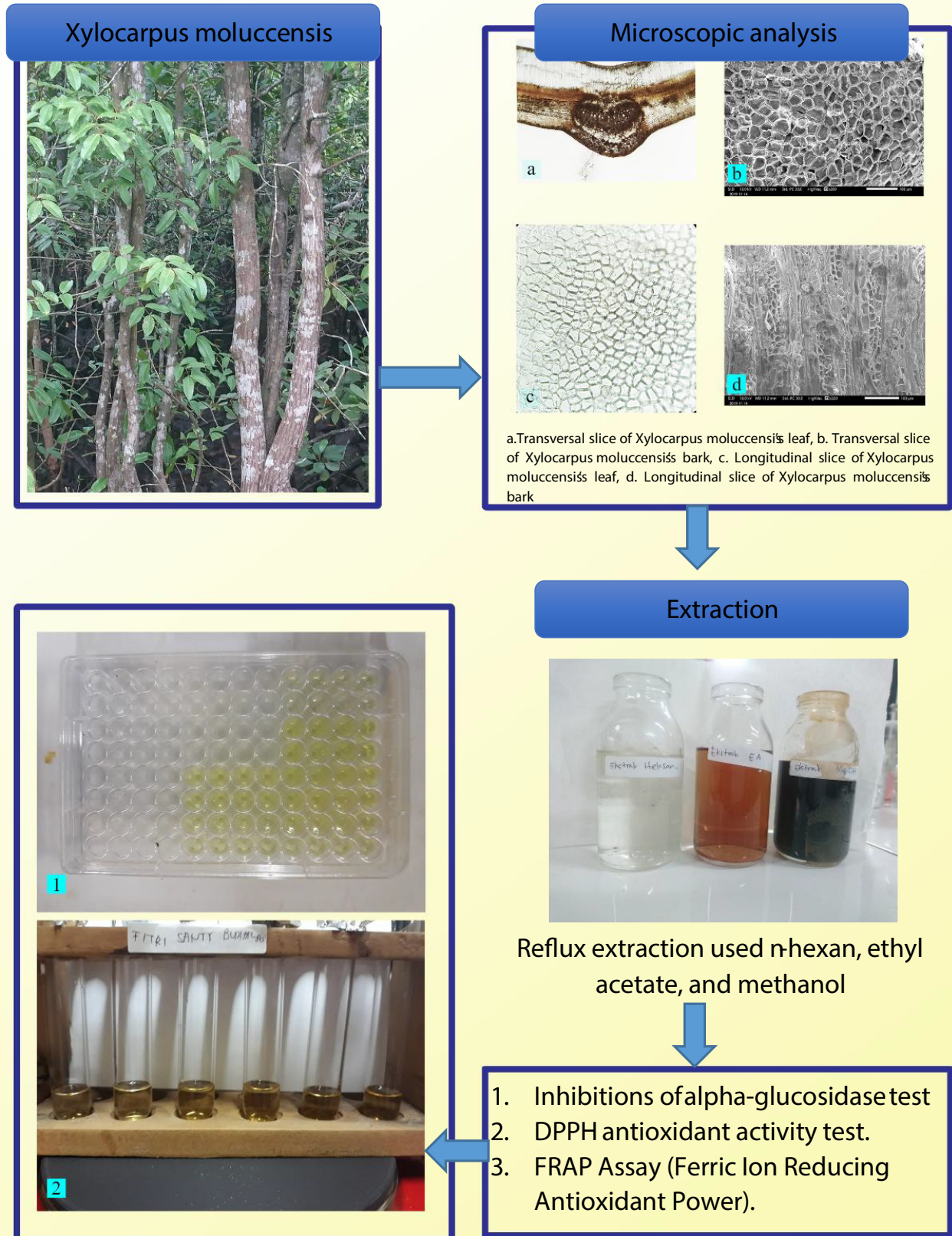

Reflux extraction used n-hexan, ethyl acetate, and methanol

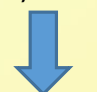

1. Inhibitions ofalpha-glucosidase test

2. DPPH antioxidant activity test.

3. FRAP Assay (Ferric lon Reducing Antioxidant Power).

\section{ABOUT AUTHORS}

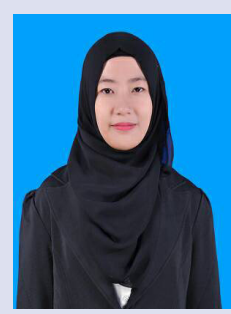

Fitri Santy Budiarso is a Pharmacist and Magister Pharmacy Student at the Faculty of Pharmacy, Universitas Indonesia, Kampus UI Depok, West Java 16424, Indonesia. She has research experience in the field of Phytochemistry and Natural Product. 


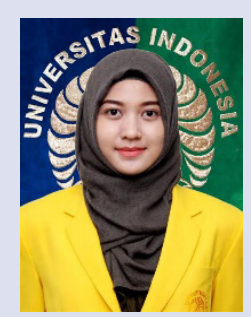

Roshamur Cahyan Forenstrania Forenstrania is a Lecturer and Researcher at the Faculty of Pharmacy, Universitas Indonesia, Kampus UI Depok, West Java 16424, Indonesia. She has research experience in the field of Pharmacognosy, Phytochemistry, and Natural Product.

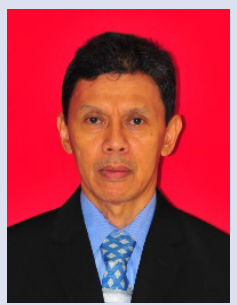

Muhammad Hanafi is a Researcher at the Research Center for Chemistry, Indonesian Institute of Sciences, PUSPITEK area, Serpong, South Tanggerang, Banten, Indonesia and Lecturer at the Faculty of Pharmacy, University of Pancasila, Srengseng Sawah, Jakarta, Indonesia.. He has research experience in the field of Natural Product.

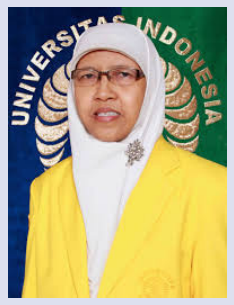

Berna Elya is a Professor and Lecturer at the Faculty of Pharmacy, Universitas Indonesia, Kampus UI Depok, West Java 16424, Indonesia. She develops works in the area of Pharmacognosy, Phytochemistry, and Natural Product.

Cite this article: Budiarso FS, Elya B, Hanafi M, Forestrania RC. The Potential of Stem Bark of Kayu Sarampa (Xylocarpus moluccensis (Lam.) M. Roen)) as $\alpha$-glucosidase Inhibitor. Pharmacogn J. 2020;12(6):1368-76. 